Supporting Information

\title{
A probe for NLRP3 inflammasome inhibitor MCC950 identifies carbonic anhydrase 2 as a novel target
}

Cassandra R. Kennedy, ${ }^{1,2, \dagger}$ Andrea Goya Grocin, ${ }^{1}$ Tristan Kovačič, ${ }^{1}$ Ravi Singh, ${ }^{1}$ Jennifer A. Ward, 1,2,§ Avinash R. Shenoy* ${ }^{3,4}$ Edward W. Tate*,1,5

${ }^{1}$ Department of Chemistry, Molecular Sciences Research Hub, Imperial College London, London W12 0BZ, United Kingdom

${ }^{2}$ Institute of Chemical Biology Centre for Doctoral Training, Imperial College London, London W12 0BZ, United Kingdom

${ }^{3}$ Medical Research Council Centre for Molecular Bacteriology and Infection, Department of Infectious Disease, Imperial College London, London SW7 2AZ, United Kingdom

${ }^{4}$ Satellite Group Leader, The Francis Crick Institute, London NW1 1AT, United Kingdom

5 The Francis Crick Institute, London NW1 1AT, United Kingdom 


\section{Table of Contents}

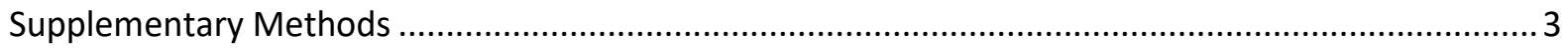

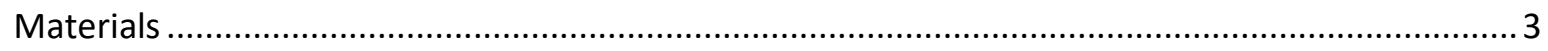

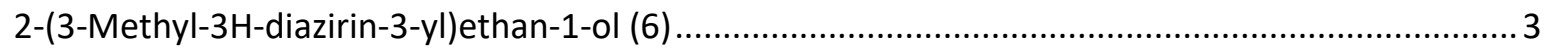

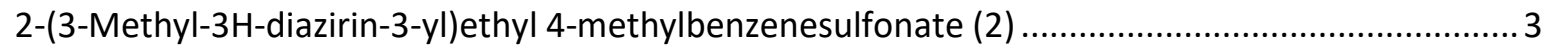

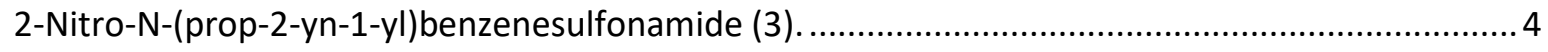

N-(2-(3-Methyl-3H-diazirin-3-yl)ethyl)-2-nitro-N-(prop-2-yn-1-yl)benzenesulfonamide (4)............4

N-(2-(3-Methyl-3H-diazirin-3-yl)ethyl)prop-2-yn-1-amine hydrochloride (5)............................5

N-(2-(3-methyl-3H-diazirin-3-yl)ethyl)-N-(prop-2-yn-1-yl)-4-sulfamoylbenzamide (6) ....................5

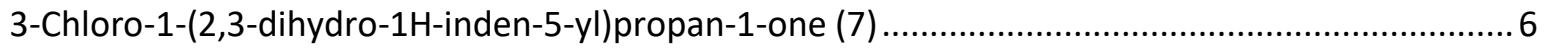

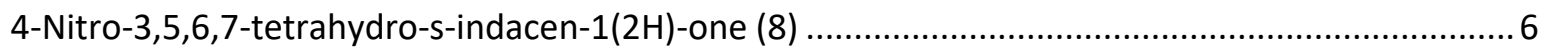

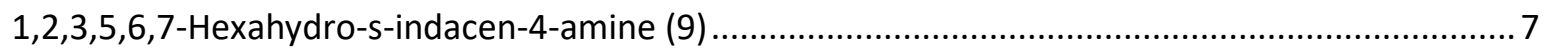

4-(N-((1,2,3,5,6,7-hexahydro-s-indacen-4-yl)carbamoyl)sulfamoyl)-N-(2-(3-methyl-3H-diazirin-3-

yl)ethyl)-N-(prop-2-yn-1-yl)benzamide (IMP2070) ...........................................................

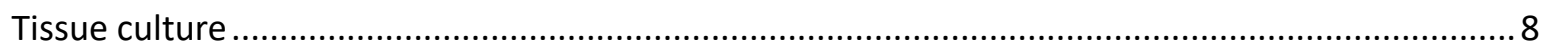

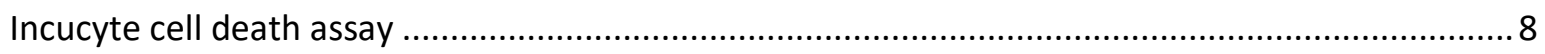

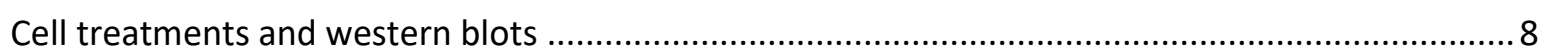

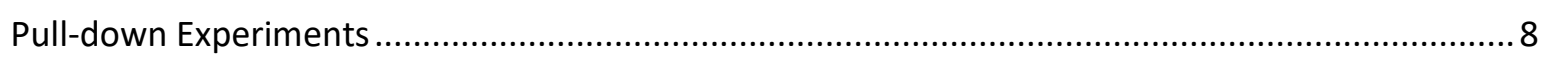

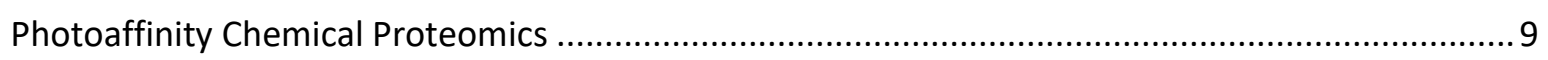

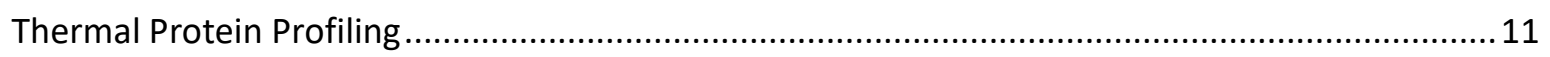

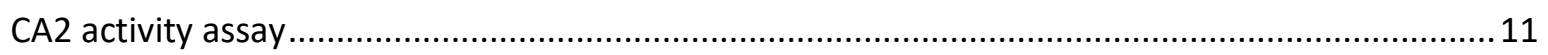

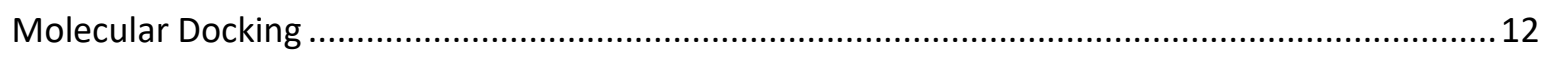

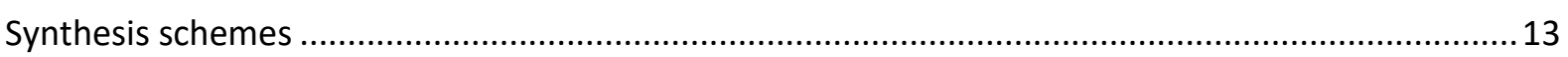

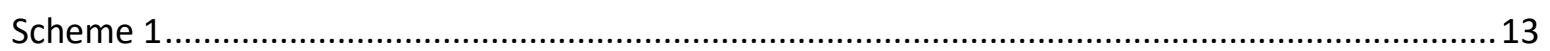

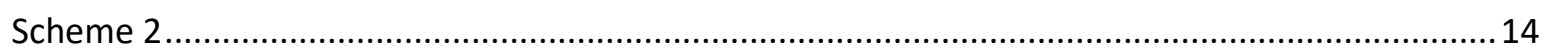

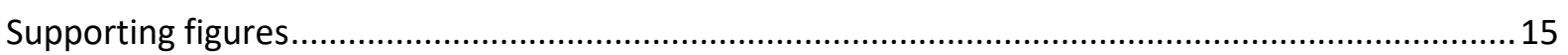

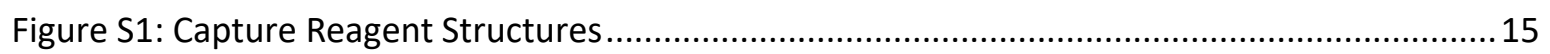

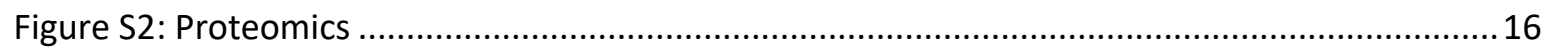

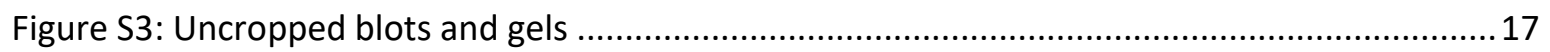

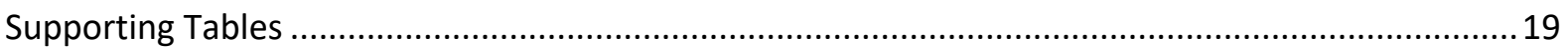

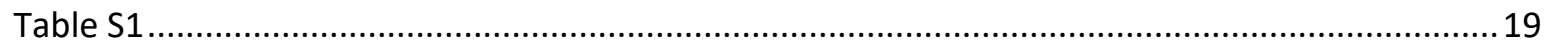




\section{Supplementary Methods}

\section{Materials}

Chemicals were purchased from Sigma-Aldrich, Fluorochem, Acros Organics, TCl, Alfa Aesar or Fisher Scientific and used without further purification. AzTB and AzRB were synthesized in-house as previously reported. NeutrAvidin agarose resin and PreScission ${ }^{\mathrm{TM}}$ Protease were purchased from Thermo Fisher Scientific. CA2 protein was purchased from Sigma-Aldrich.

\section{2-(3-Methyl-3H-diazirin-3-yl)ethan-1-ol (1)}

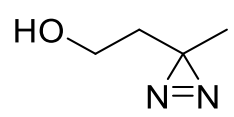

Ammonia $(100 \mathrm{~mL})$ was condensed at $-78{ }^{\circ} \mathrm{C}$ into a $250 \mathrm{~mL}$ round bottom flask fitted with a cold finger of dry ice-acetone and a $6 \mathrm{M} \mathrm{HCl}_{\text {(aq) }}$ trap. 4-Hydroxybutan-2-one $(10.0 \mathrm{~g}$, $113 \mathrm{mmol})$ dissolved in dry $\mathrm{MeOH}(15.4 \mathrm{~mL})$ was added to the reaction vessel and stirred at $78{ }^{\circ} \mathrm{C}$. After $5 \mathrm{~h}$, hydroxylamine-O-sulphonic acid $(16.7 \mathrm{~g}, 159 \mathrm{mmol})$ dissolved in anhydrous $\mathrm{MeOH}(108 \mathrm{~mL})$ was added dropwise at $-78^{\circ} \mathrm{C}$ and the reaction stirred and allowed to warm to RT overnight. The reaction mixture was then filtered, and the solids washed with anhydrous $\mathrm{MeOH}(2 \times 30 \mathrm{~mL})$. The filtrate was concentrated under reduced pressure at $30^{\circ} \mathrm{C}$ and the residue re-dissolved in anhydrous $\mathrm{MeOH}(77 \mathrm{~mL})$, cooled to $0^{\circ} \mathrm{C}$, and DIPEA $(23 \mathrm{~mL}$, $136.2 \mathrm{mmol}$ ) was added. $\mathrm{I}_{2}$ was added portion-wise until a dark brown colour persisted for $1 \mathrm{~h}$. The reaction mixture was diluted with $\mathrm{Et}_{2} \mathrm{O}(230 \mathrm{~mL}), \mathrm{HCl}_{(\mathrm{aq})}(1 \mathrm{M}, 230 \mathrm{~mL})$ and phases separated. The aqueous phase was extracted with $\mathrm{Et}_{2} \mathrm{O}(2 \times 150 \mathrm{~mL})$ and the combined organic phases washed successively with $\mathrm{HCl}_{(\text {aq })}(1 \mathrm{M}, 230 \mathrm{~mL}), \mathrm{Na}_{2} \mathrm{~S}_{2} \mathrm{O}_{3}(\mathrm{aq})(10 \%, 230 \mathrm{~mL})$ and brine $(230 \mathrm{~mL})$. The organic phase was dried over anhydrous $\mathrm{MgSO}_{4}$, filtered and concentrated under reduced pressure to give title compound 1 as a pale-yellow oil ( $3.90 \mathrm{~g}$, $39.0 \mathrm{mmol}, 34 \%)$. $\mathrm{R}_{\mathrm{f}} 0.53(10 \% \mathrm{DCM}$ in $\mathrm{MeOH}) ;{ }^{1} \mathrm{H}$ NMR $(400 \mathrm{MHz}$, Chloroform- $d$ ) $\delta 3.50$ (t, $J=6.4 \mathrm{~Hz}, 2 \mathrm{H}), 2.64-2.38(\mathrm{~m}, 1 \mathrm{H}), 1.60(\mathrm{t}, J=6.4 \mathrm{~Hz}, 2 \mathrm{H}), 1.04(\mathrm{~s}, 3 \mathrm{H}) ;{ }^{13} \mathrm{C}$ NMR $(101 \mathrm{MHz}$, Chloroform-d) $\delta 65.82,57.53,37.50,20.16$.

\section{2-(3-Methyl-3H-diazirin-3-yl)ethyl 4-methylbenzenesulfonate (2)}<smiles>Cc1ccc(S(=O)(=O)OCCC2(C)N=N2)cc1</smiles>

2

4-Methylbenzenesulfonyl chloride $(11.7 \mathrm{~g}, 61.5 \mathrm{mmol})$ was added portion-wise to a solution of compound $1(4.09 \mathrm{~g}, 41.0 \mathrm{mmol})$ in pyridine $(33 \mathrm{~mL})$ at $0^{\circ} \mathrm{C}$, allowed to warm to RT and stirred. After $3 \mathrm{~h}$, the reaction mixture was diluted with $\mathrm{DCM}(600 \mathrm{~mL})$ and $\mathrm{HCl}_{(\mathrm{aq})}(1 \mathrm{M}$, $600 \mathrm{~mL}$ ), separated, and the organic phase washed successively with $\mathrm{HCl}($ aq) $(1 \mathrm{M}, 200 \mathrm{~mL})$, saturated $\mathrm{NaHCO}_{3}$ (aq) $(600 \mathrm{~mL})$, brine $(600 \mathrm{~mL})$, dried over $\mathrm{MgSO}_{4}$, filtered and concentrated under reduced pressure. The crude product was purified by automated flash column chromatography (8-66\% EtOAc in hexane) to give title compound 2 as a colourless oil $(6.75 \mathrm{~g}$, $26.5 \mathrm{mmol}, 65 \%)$. $\mathrm{R}_{\mathrm{f}} 0.57$ (100\% DCM); ${ }^{1} \mathrm{H}$ NMR (400 MHz, Chloroform- $\left.d\right) \delta 7.86-7.79$ (m, 2H), $7.38(\mathrm{~d}, J=7.9 \mathrm{~Hz}, 2 \mathrm{H}), 3.97(\mathrm{t}, J=6.4 \mathrm{~Hz}, 2 \mathrm{H}), 2.47(\mathrm{~s}, 3 \mathrm{H}), 1.69(\mathrm{t}, J=6.4 \mathrm{~Hz}, 2 \mathrm{H})$, 
1.02 (s, 3H); ${ }^{13} \mathrm{C}$ NMR (101 MHz, Chloroform-d) $\delta 145.05,132.77,129.92,127.98,65.10$, 34.18, 23.37, 21.65, 19.76.

\section{2-Nitro-N-(prop-2-yn-1-yl)benzenesulfonamide (3)}<smiles>C#CCNS(=O)(=O)c1ccccc1[N+](=O)[O-]</smiles>

3

$\mathrm{Et}_{3} \mathrm{~N}(7.59 \mathrm{~mL}, 54.5 \mathrm{mmol})$ was added to a solution of prop-2-yn-1-amine 2 (3.00 g, $54.5 \mathrm{mmol})$ in DCM $(45 \mathrm{~mL})$ and cooled to $0^{\circ} \mathrm{C}$ under nitrogen. 2-Nitrobenzenesulfonyl chloride $(11.4 \mathrm{~g}, 51.4 \mathrm{mmol}$ ) was added and the reaction stirred at RT. After $3 \mathrm{~h}$, the reaction mixture was diluted with $\mathrm{DCM}(150 \mathrm{~mL})$ and $\mathrm{HCl}_{(\mathrm{aq})}(2 \mathrm{M}, 150 \mathrm{~mL})$ and separated. The aqueous phase was extracted with DCM $(150 \mathrm{~mL})$ and the combined organic phases washed successively with $\mathrm{HCl}_{(\mathrm{aq})}(2 \mathrm{M}, 225 \mathrm{~mL}), \mathrm{H}_{2} \mathrm{O}(225 \mathrm{~mL})$, and brine $(75 \mathrm{~mL})$. The organic phase was dried over $\mathrm{Na}_{2} \mathrm{SO}_{4}$, filtered and concentrated under reduced pressure. The resulting residue was purified by automated flash column chromatography on silica gel (10 - 50\% EtOAc in hexane) to give title compound 3 as a pale-orange solid $(11.1 \mathrm{~g}, 46.3 \mathrm{mmol}, 90 \%)$. $\mathrm{R}_{\mathrm{f}} 0.46$ (50\% EtOAc in hexane); ${ }^{1} \mathrm{H}$ NMR $(400 \mathrm{MHz}$, Chloroform- $d) \delta 8.31-8.17(\mathrm{~m}, 1 \mathrm{H}), 7.98-7.91$ $(\mathrm{m}, 1 \mathrm{H}), 7.82-7.74(\mathrm{~m}, 2 \mathrm{H}), 5.71(\mathrm{t}, \mathrm{J}=6.3 \mathrm{~Hz}, 1 \mathrm{H}), 4.04(\mathrm{dd}, \mathrm{J}=6.1,2.7 \mathrm{~Hz}, 2 \mathrm{H}), 2.00(\mathrm{t}, \mathrm{J}$ $=2.5 \mathrm{~Hz}, 1 \mathrm{H}) ;{ }^{13} \mathrm{C}$ NMR $(101 \mathrm{MHz}$, Chloroform- $d) \delta 134.04,133.80,132.90,131.59,125.77$, $125.53,77.21,73.26,33.40$.

N-(2-(3-Methyl-3H-diazirin-3-yl)ethyl)-2-nitro-N-(prop-2-yn-1-yl)benzenesulfonamide (4)<smiles>C#CCN(CCC1(C)N=N1)S(=O)(=O)c1ccccc1[N+](=O)[O-]</smiles>

4

$\mathrm{K}_{2} \mathrm{CO}_{3}(18.8 \mathrm{~g}, 136.0 \mathrm{mmol})$ and compound 3 (10.9 g, $\left.45.34 \mathrm{mmol}\right)$ were added sequentially to a stirred solution of $7(11.5 \mathrm{~g}, 45.3 \mathrm{mmol})$ in DMF $(92 \mathrm{~mL})$ and the reaction stirred at $80^{\circ} \mathrm{C}$. After $3 \mathrm{~h}$, the reaction mixture was diluted with EtOAc $(450 \mathrm{~mL})$ and $\mathrm{H}_{2} \mathrm{O}(450 \mathrm{~mL})$ and separated. The aqueous phase was extracted with EtOAc $(2 \times 300 \mathrm{~mL})$ and the combined organic phases washed successively with $\mathrm{LiCl}_{(\mathrm{aq})}(5 \%, 2 \times 600 \mathrm{~mL})$ and brine $(600 \mathrm{~mL})$. The organic phase was dried over $\mathrm{MgSO}_{4}$, filtered and concentrated in vacuo. The crude product was purified by flash column chromatography on silica gel (33\% EtOAc in hexane) to give title compound 4 as a pale yellow oil $(9.50 \mathrm{~g}, 29.5 \mathrm{mmol}, 65 \%)$. $\mathrm{R}_{\mathrm{f}} 0.22$ (33\% EtOAc in hexane); ${ }^{1} \mathrm{H}$ NMR $(400 \mathrm{MHz}$, Chloroform- $d) \delta 8.08-8.03(\mathrm{~m}, 1 \mathrm{H}), 7.75-7.69(\mathrm{~m}, 2 \mathrm{H}), 7.67-7.63(\mathrm{~m}$, $1 \mathrm{H}), 4.18(\mathrm{~d}, J=2.5 \mathrm{~Hz}, 2 \mathrm{H}), 3.46-3.40(\mathrm{~m}, 2 \mathrm{H}), 2.18(\mathrm{t}, J=2.4 \mathrm{~Hz}, 1 \mathrm{H}), 1.67-1.60(\mathrm{~m}$, $2 \mathrm{H}), 1.06(\mathrm{~s}, 3 \mathrm{H}) ;{ }^{13} \mathrm{C}$ NMR (101 MHz, Chloroform-d) $\delta 148.31,133.94,132.34,131.74$, 130.94, 124.26, 76.37, 74.30, 60.38, 42.18, 36.69, 33.30, 19.34. 


\section{N-(2-(3-Methyl-3H-diazirin-3-yl)ethyl)prop-2-yn-1-amine hydrochloride (5)}

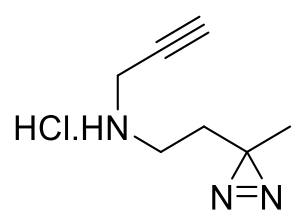

5

$\mathrm{LiOH} \cdot \mathrm{H}_{2} \mathrm{O}(4.95 \mathrm{~g}, 118.0 \mathrm{mmol})$ and 3-mercaptopropanoic acid $(5.26 \mathrm{~mL}, 59.0 \mathrm{mmol})$ were added to a stirred solution of compound $4(9.50 \mathrm{~g}, 29.5 \mathrm{mmol})$ in DMF $(73 \mathrm{~mL})$ and the reaction stirred at RT. After $5 \mathrm{~h}$, the reaction mixture was diluted with EtOAc $(600 \mathrm{~mL})$ and $\mathrm{H}_{2} \mathrm{O}$ $(600 \mathrm{~mL})$ and separated. The aqueous phase was extracted with EtOAc $(2 \times 600 \mathrm{~mL})$ and the combined organic phases washed successively with $\mathrm{LiCl}_{(\mathrm{aq})}(5 \%, 1200 \mathrm{~mL})$, saturated $\mathrm{NaHCO}_{3}$ (aq) $(1200 \mathrm{~mL})$ and brine $(600 \mathrm{~mL})$. The organic phase was dried over $\mathrm{MgSO}_{4}$, filtered and concentrated under reduced pressure. Hydrochloric acid (4 N in 1,4-dioxane, $7.97 \mathrm{~mL}$ ) was added to the resulting residue at $0^{\circ} \mathrm{C}$ and stirred. After $20 \mathrm{~min}$, the mixture was diluted with $\mathrm{Et}_{2} \mathrm{O}(200 \mathrm{~mL})$, warmed to $\mathrm{RT}$ and filtered. The solids were washed with $\mathrm{Et}_{2} \mathrm{O}(20 \mathrm{~mL})$ and collected to give title compound 5 as a white powder $(3.000 \mathrm{~g}, 17.3 \mathrm{mmol}, 59 \%)$. $\mathrm{R}_{\mathrm{f}} 0.22$ (50\% EtOAc in hexane); ${ }^{1} \mathrm{H}$ NMR $\left(400 \mathrm{MHz}, \mathrm{DMSO}_{-} \mathrm{d}_{6}\right) \delta 9.24(\mathrm{~s}, 2 \mathrm{H}), 3.89(\mathrm{~d}, J=2.6 \mathrm{~Hz}$, $2 \mathrm{H}), 3.73(\mathrm{t}, J=2.5 \mathrm{~Hz}, 1 \mathrm{H}), 2.96-2.87(\mathrm{~m}, 2 \mathrm{H}), 1.71-1.65(\mathrm{~m}, 2 \mathrm{H}), 1.05(\mathrm{~s}, 3 \mathrm{H}) ;{ }^{13} \mathrm{C} N M R$ $\left(101 \mathrm{MHz}, \mathrm{DMSO}-\mathrm{d}_{6}\right) \delta$ 79.95, 76.23, 65.97, 41.60, 36.07, 31.03, 23.03.

\section{N-(2-(3-methyl-3H-diazirin-3-yl)ethyl)-N-(prop-2-yn-1-yl)-4-sulfamoylbenzamide (6)}<smiles>C#CCN(CCC1(C)N=N1)C(=O)c1ccc(S(N)(=O)=O)cc1</smiles>

6

To a solution of $\mathrm{N}$-(2-(3-methyl-3H-diazirin-3-yl)ethyl)prop-2-yn-1-amine hydrochloride 5 $(100 \mathrm{mg}, 0.576 \mathrm{mmol})$ in DMF $(15 \mathrm{~mL})$ was added 4-sulfamoylbenzoic acid $(116 \mathrm{mg}$, $0.576 \mathrm{mmol}$ ) followed by propanephosphonic acid anhydride $(700 \mu \mathrm{L}, 367 \mathrm{mg}, 1.15 \mathrm{mmol}$; $50 \%$ in EtOAc), and DIPEA ( $301 \mu \mathrm{L}, 1.73 \mathrm{mmol})$. The reaction was stirred overnight at RT and diluted with EtOAc $(50 \mathrm{~mL})$. The organic phase was washed with saturated $\mathrm{NaHCO}_{3}(\mathrm{aq})$ $(50 \mathrm{~mL}), 5 \% \mathrm{LiCl}_{(\mathrm{aq})}(2 \times 50 \mathrm{~mL})$ and brine $(50 \mathrm{~mL})$ and dried over $\mathrm{MgSO}_{4}$, filtered, and EtOAc evaporated under reduced pressure. The crude product was dry-loaded onto a C-18 reversephased column and purified using automated column chromatography, eluting with a gradient of $\mathrm{MeCN} / \mathrm{H}_{2} \mathrm{O}(50-98 \%)$ to afford the title compound 6 as a white solid (80 mg; $0.25 \mathrm{mmol}$; 43\%). ${ }^{1} \mathrm{H}$ NMR $\left(400 \mathrm{MHz}\right.$, DMSO-d $\left.6,100{ }^{\circ} \mathrm{C}\right) \delta 7.92(\mathrm{~d}, \mathrm{~J}=8.7 \mathrm{~Hz}, 2 \mathrm{H}), 7.58(\mathrm{~d}, \mathrm{~J}=8.7 \mathrm{~Hz}$, 2H), $7.18(\mathrm{~s}, 2 \mathrm{H}), 4.11(\mathrm{~d}, \mathrm{~J}=2.4 \mathrm{~Hz}, 2 \mathrm{H}), 3.44(\mathrm{t}, \mathrm{J}=7.5 \mathrm{~Hz}, 2 \mathrm{H}), 3.13(\mathrm{t}, \mathrm{J}=2.4 \mathrm{~Hz}, 1 \mathrm{H})$, $1.70(\mathrm{t}, \mathrm{J}=7.6 \mathrm{~Hz}, 2 \mathrm{H}), 1.00(\mathrm{~s}, 2 \mathrm{H}) ;{ }^{13} \mathrm{C}$ NMR $\left(101 \mathrm{MHz}, \mathrm{DMSO}-\mathrm{d}_{6}, 100{ }^{\circ} \mathrm{C}\right) \delta 168.64,144.79$, $138.48,126.39,125.38,78.65,74.35,41.26,31.79,23.62,18.60$, one quaternary carbon was not observed; LC-MS 18 minutes, 50-98\% MeCN in $\mathrm{H}_{2} \mathrm{O}$, retention time 9.09 minutes, $\mathrm{ESI} \mathrm{m} / \mathrm{z}$ $[\mathrm{M}+\mathrm{H}]^{+}=321.17$; HRMS found $319.0869\left(\mathrm{C}_{14} \mathrm{H}_{15} \mathrm{~N}_{4} \mathrm{O}_{3} \mathrm{~S} \text {, [M-H] }\right]^{-}$requires 319.0870$)$; IR vmax/cm-1 $1624(\mathrm{C}=\mathrm{O})$. 


\section{3-Chloro-1-(2,3-dihydro-1H-inden-5-yl)propan-1-one (7)}<smiles>O=C(CCCl)c1ccc2c(c1)CCC2</smiles>

7

Aluminium chloride $(6.76 \mathrm{~g}, 50.8 \mathrm{mmol})$ was added portion-wise to a solution of indan $(5.18 \mathrm{~mL}, 42.3 \mathrm{mmol})$ and 3-chloropropionyl chloride $(4.44 \mathrm{~mL}, 46.5 \mathrm{mmol})$ in DCM $(60 \mathrm{~mL})$ at room temperature (RT). The reaction quenched after two hours by addition of ice-cold $2 \mathrm{M}$ $\mathrm{HCl}_{(\mathrm{aq})}(60 \mathrm{~mL})$. The organic layer was extracted with $\mathrm{DCM}(2 \times 200 \mathrm{~mL})$, washed with brine $(100 \mathrm{~mL})$, dried $\left(\mathrm{MgSO}_{4}\right)$ and concentrated under reduced pressure to yield a brown oil. Addition of $15 \%$ ethyl acetate in hexane resulted in precipitate formation which was filtered to give the title compound 7 as pale brown crystals $(7.62 \mathrm{~g}, 36.6 \mathrm{mmol}, 72 \%)$. $\mathrm{R}_{\mathrm{f}} 0.48(10 \%$ EtOAc in hexane); ${ }^{1} \mathrm{H}$ NMR $(400 \mathrm{MHz}$, Chloroform- $d) \delta 7.85-7.72(\mathrm{~m}, 2 \mathrm{H}), 7.34-7.27(\mathrm{~m}$, $1 \mathrm{H}), 3.92(\mathrm{t}, \mathrm{J}=6.9 \mathrm{~Hz}, 2 \mathrm{H}), 3.44(\mathrm{t}, \mathrm{J}=6.9 \mathrm{~Hz}, 2 \mathrm{H}), 2.96(\mathrm{t}, \mathrm{J}=7.5 \mathrm{~Hz}, 4 \mathrm{H}), 2.19-2.06(\mathrm{~m}$, $2 \mathrm{H}) ;{ }^{13} \mathrm{C}$ NMR (101 MHz, Chloroform-d) $\delta 196.83,150.97,145.13,135.09,126.75,124.63$, 124.12, 41.48, 39.11, 33.20, 32.70, 25.49; HRMS found $208.0660\left(\mathrm{C}_{12} \mathrm{H}_{13} \mathrm{ClO}\right.$, [M+•] requires 208.0655).

\section{4-Nitro-3,5,6,7-tetrahydro-s-indacen-1(2H)-one (8)}<smiles>O=C1CCc2cc3c(c([N+](=O)[O-])c21)CCC3</smiles>

8

Compound 7 (3.0 g, $14.4 \mathrm{mmol})$ was added portion-wise to concentrated sulphuric acid $(15 \mathrm{~mL})$ at $\mathrm{RT}$. The mixture was heated to $55^{\circ} \mathrm{C}$ and stirred for 48 hours. The reaction mixture was not purified and taken forwards crude. The reaction was cooled on ice, and a 1:1 mixture of concentrated nitric and sulphuric acid $(3 \mathrm{~mL})$ added. The solution was then stirred at $0-5^{\circ} \mathrm{C}$ for 1 hour. The reaction was quenched by dropwise addition to a mixture of water $(125 \mathrm{~mL})$ and DCM $(125 \mathrm{~mL})$ on ice. The organic layer was collected, and the aqueous layer extracted with DCM $(2 \times 125 \mathrm{~mL})$. Combined organic layers were washed with saturated $\mathrm{NaHCO}_{3}(\mathrm{aq})$ $(100 \mathrm{~mL})$, before drying with magnesium sulphate and concentrated in vacuo to give a brown oil. The crude reaction was purified using silica, eluting with a gradient of EtOAc/hexane (15$20 \%$ ) to afford three isomers. The title compound 8 was isolated as pale yellow crystals (1.640 g, 52.4\%). $\mathrm{R}_{\mathrm{f}} 0.19$ (20\% EtOAc in hexane); HRMS found $217.0739\left(\mathrm{C}_{12} \mathrm{H}_{11} \mathrm{NO}_{3}, \mathrm{M}^{+*}\right]$ requires 217.0743); ${ }^{1} \mathrm{H}$ NMR $(400 \mathrm{MHz}$, Chloroform- $d) \delta 7.44(\mathrm{~s}, 1 \mathrm{H}), 3.12(\mathrm{t}, \mathrm{J}=5.8 \mathrm{~Hz}, 2 \mathrm{H})$, $3.04(\mathrm{t}, \mathrm{J}=7.4 \mathrm{~Hz}, 2 \mathrm{H}), 2.99(\mathrm{t}, \mathrm{J}=7.6 \mathrm{~Hz}, 2 \mathrm{H}), 2.77(\mathrm{~m}, 2 \mathrm{H}), 2.20(\mathrm{p}, 121 \mathrm{~J}=7.4,7.6 \mathrm{~Hz}$, $2 \mathrm{H})$. 


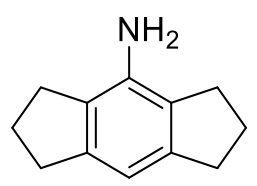

9

To a solution of 4-Nitro-3,5,6,7-tetrahydro-s-indacen-1(2H)-one 8 (250 mg, $1.15 \mathrm{mmol})$ in methanol $(12.5 \mathrm{~mL})$ were added Pearlman's catalyst $(62.5 \mathrm{mg}, 20 \%$ wt on carbon) and methanesulfonic acid $\left(120 \mu \mathrm{L}, 70 \%\right.$ wt in $\left.\mathrm{H}_{2} \mathrm{O}\right)$ before agitation under a hydrogenous atmosphere at 50 psi. The reaction was monitored by TLC and after four hours the reaction was poured over Celite, and the filtrate was washed with $\mathrm{MeOH}$ before concentration under reduced pressure. The crude solid was purified on silica gel, eluting with 10\% EtOAc/hexane to afford the title compound 9 as brown wax (147 mg, $0.85 \mathrm{mmol}, 74 \%)$. $\mathrm{R}_{\mathrm{f}} 0.35$ (10\% EtOAc in hexane); ${ }^{1} \mathrm{H}$ NMR (400 MHz, Chloroform- $\left.d\right) \delta 6.63(\mathrm{~s}, 1 \mathrm{H}), 3.50(\mathrm{~s}, 2 \mathrm{H}), 2.87$ (t, J = $7.5 \mathrm{~Hz}$, $4 \mathrm{H}), 2.69(\mathrm{t}, \mathrm{J}=7.3 \mathrm{~Hz}, 4 \mathrm{H}), 2.11(\mathrm{p}, \mathrm{J}=7.5,7.3 \mathrm{~Hz}, 4 \mathrm{H}) ;{ }^{13} \mathrm{C}$ NMR $(101 \mathrm{MHz}$, Chloroform- $d$ ) $\delta$ 144.12, 138.38, 126.33, 110.86, 33.18, 29.10, 25.63; HRMS found $174.1284\left(\mathrm{C}_{12} \mathrm{H}_{16} \mathrm{~N}\right.$, $[\mathrm{M}+\mathrm{H}]^{+}$requires 174.1277$)$.

\section{4-(N-((1,2,3,5,6,7-hexahydro-s-indacen-4-yl)carbamoyl)sulfamoyl)-N-(2-(3-methyl-3H- diazirin-3-yl)ethyl)-N-(prop-2-yn-1-yl)benzamide (IMP2070)}<smiles>C#CCN(CCC1(C)N=N1)C(=O)c1ccc(S(=O)(=O)NC(=O)Nc2c3c(cc4c2CCC4)CCC3)cc1</smiles>

IMP2070

Triphosgene $(45.7 \mathrm{mg}, 0.154 \mathrm{mmol})$ in THF $(154 \mu \mathrm{L})$ was added to a solution of triethylamine $(129 \mu \mathrm{L}, 0.923 \mathrm{mmol})$ and compound $9(80 \mathrm{mg}, 0.462 \mathrm{mmol})$ in THF $(10 \mathrm{~mL})$. The reaction mixture was refluxed for three hours and the reaction was taken to the next step without any purification. To a solution of molecule $6(75 \mathrm{mg}, 0.234 \mathrm{mmol})$ in THF $(5 \mathrm{~mL})$ was added $\mathrm{NaOMe}(13 \mathrm{mg}, 0.234 \mathrm{mmol})$ and the reaction was stirred for one hour. The crude isocyanate was added dropwise to the reaction mixture and stirred overnight. The reaction mixture was filtered, and the filtrate dry-loaded onto a C-18 reverse-phased column and purified using automated column chromatography, eluting with a gradient of $\mathrm{MeCN} / \mathrm{H}_{2} \mathrm{O}(50-98 \%)$ to afford the title compound IMP2070 as a white solid (12 mg, $0.023 \mathrm{mmol}, 10 \%) .{ }^{1} \mathrm{H}$ NMR $(400 \mathrm{MHz}$, DMSO- $\left._{6}, 100{ }^{\circ} \mathrm{C}\right) \delta 7.93(\mathrm{~d}, \mathrm{~J}=8.6 \mathrm{~Hz}, 2 \mathrm{H}), 7.58(\mathrm{~d}, \mathrm{~J}=8.6 \mathrm{~Hz}, 2 \mathrm{H}), 7.18(\mathrm{~s}, 2 \mathrm{H}), 6.38(\mathrm{~s}$, $1 \mathrm{H}), 4.11(\mathrm{~d}, \mathrm{~J}=2.6 \mathrm{~Hz}, 2 \mathrm{H}), 3.44(\mathrm{t}, \mathrm{J}=7.5 \mathrm{~Hz}, 2 \mathrm{H}), 3.13(\mathrm{t}, \mathrm{J}=2.6 \mathrm{~Hz}, 1 \mathrm{H}), 2.75$ (t, J = $7.4 \mathrm{~Hz}, 4 \mathrm{H}), 2.62(\mathrm{t}, \mathrm{J}=7.4 \mathrm{~Hz}, 4 \mathrm{H}), 2.00(\mathrm{p}, \mathrm{J}=7.4,7.4 \mathrm{~Hz}, 4 \mathrm{H}), 1.70(\mathrm{t}, \mathrm{J}=7.5 \mathrm{~Hz}, 2 \mathrm{H}), 1.00$ $(\mathrm{s}, 3 \mathrm{H}) ;{ }^{13} \mathrm{C}$ NMR $\left(101 \mathrm{MHz}, \mathrm{DMSO}-\mathrm{d}_{6}, 100^{\circ} \mathrm{C}\right) \delta 168.66,149.16,144.82,142.08,138.90$, 138.50, 126.41, 125.40, 124.55, 108.18, 78.67, 74.38, 41.29, 32.11, 31.81, 28.29, 24.34, 23.66, 18.62, one quaternary carbon was not observed; LC-MS 18 minutes, $50-98 \%$ MeCN in $\mathrm{H}_{2} \mathrm{O}$, retention time 8.52 minutes, $\mathrm{ESI} \mathrm{m} / \mathrm{z}[\mathrm{M}+\mathrm{H}]^{+}=520.30$; HRMS found 518.1874 $\left(\mathrm{C}_{27} \mathrm{H}_{28} \mathrm{~N}_{5} \mathrm{O}_{4} \mathrm{~S},[\mathrm{M}-\mathrm{H}]^{-}\right.$requires 518.1862); IR vmax/cm-1 $1622(\mathrm{C}=\mathrm{O}), 1582(\mathrm{C}=\mathrm{O})$. 


\section{Tissue culture}

Wild-type (WT) THP1 cells were grown at $37{ }^{\circ} \mathrm{C}$ in a $5 \% \mathrm{CO}_{2}$ incubator, and mycoplasma tests performed monthly. WT THP1 cells were cultured in RPMI medium (Sigma Aldrich) supplemented with $10 \%$ heat inactivated Fetal Bovine Serum (FBS), $1 \mathrm{mM}$ sodium pyruvate (Sigma Aldrich) and $10 \mathrm{mM}$ HEPES (Sigma Aldrich). THP1 cells were differentiated into macrophages using $100 \mathrm{ng} \mathrm{mL}^{-1} \mathrm{PMA}$ for 72 hours prior to treatments. Unless otherwise stated, media was refreshed before treatments began.

\section{Incucyte cell death assay}

THP1 cells were seeded in 96 well plates with $1.5 \times 10^{5}$ cells per well 72 hours prior to the assay. Cells were treated in triplicate with $250 \mathrm{ng} \mathrm{mL}^{-1}$ LPS and either MCC950 or IMP2070 with a dilution concentration range $24 \mathrm{nM}-50 \mu \mathrm{M}$, in media containing $250 \mathrm{nM}$ Sytox Green. After incubation for 3 hours, the cells were treated with $10 \mu \mathrm{M}$ nigericin and placed in the Incucyte. Green filter and phase readings were taken of the wells after 1 hour.

\section{Cell treatments and Western blots}

THP1 cells were seeded in 24 well plates with $7.5 \times 10^{5}$ cells per well 72 hours prior to the assay. Cells were treated for 3 hours with $250 \mathrm{ng} \mathrm{mL}^{-1}$ LPS and either MCC950 or IMP2070 with a dilution concentration range $0.5-20 \mu \mathrm{M}$. Cells were then treated with OptiMEM (Gibco) containing $10 \mu \mathrm{M}$ nigericin. After 1 hour, supernatants were collected and remaining cells lysed in $1 \%$ Triton, $0.1 \%$ SDS, $1 \times$ protease inhibitor in $1 \times$ PBS. Supernatant were precipitated with the sequential addition of $1 \mathrm{vol} \mathrm{H}_{2} \mathrm{O}, 2$ vol $\mathrm{MeOH}$ and $0.5 \mathrm{vol} \mathrm{CHCl}_{3}$, before centrifugation at $4{ }^{\circ} \mathrm{C}$ at $17,000 \times \mathrm{g}$ for 10 minutes. The top layer of supernatant was removed by pipetting, without disrupting the pellet. A further 3 vol MeOH was added to wash the pellet, and samples sonicated. Samples were then centrifuged for ten minutes at $4{ }^{\circ} \mathrm{C}$ at $17,000 \times \mathrm{g}$ before tipping off the supernatant and drying the protein pellets at RT for 30 minutes, or until the pellets were visibly dry, before resuspension in NuPAGE LDS sample buffer with $5 \% \beta$ mercaptoethanol. Lysates were centrifuged at $4{ }^{\circ} \mathrm{C}$ at $17,000 \times \mathrm{g}$ for 10 minutes before dilution with the same loading buffer. Proteins were separated by mass by SDS-PAGE before being transferred to nitrocellulose membranes by wet transfer at $100 \mathrm{~V}$ for 1 hour. Membranes were blocked in 5\% fat free milk in TBST for one hour at RT, before incubation at $4{ }^{\circ} \mathrm{C}$ overnight with the desired primary antibodies. Membranes were incubated with secondary antibodies for one hour at RT. Blots were imaged following addition of HRP luminata solution, using an ImageQuant LAS 400 imager.

\begin{tabular}{|l|l|l|l|}
\hline Antibody & Source & Buffer & Dilution \\
\hline$\alpha$-Caspase-1 & Adipogen, AG-20B-0048-C100 & $5 \%$ milk in TBST & 1 in 1000 \\
\hline$\alpha-$-IL-1 $\beta$ & R\&D Systems, MAB201 & $5 \%$ milk in TBST & 1 in 1000 \\
\hline$\alpha-N L R P 3$ & Adipogen, AG-20B-0014-C100 & $5 \%$ BSA in TBST & 1 in 1000 \\
\hline$\alpha$-GAPDH & Abcam, ab9485 & $5 \%$ milk in TBST & 1 in 1000 \\
\hline$\alpha-H S P 90$ & SantaCruz, sc-69703 & $5 \%$ milk in TBST & 1 in 1000 \\
\hline$\alpha-$-rabbit-HRP & Advansta, R-05072-500 & $5 \%$ milk in TBST & 1 in 10,000 \\
\hline$\alpha-m o u s e-H R P$ & Advansta, R-05071-500 & $5 \%$ milk in TBST & 1 in 10,000 \\
\hline
\end{tabular}

\section{Pull-down Experiments}

THP1 cells were seeded in 6 well plates with $3 \times 10^{6}$ cells per well 72 hours prior to the assay. Cells were treated with $250 \mathrm{ng} \mathrm{mL}^{-1}$ LPS and IMP2070 with or without MCC950. After incubation for 3 hours, cells were UV irradiated with $365 \mathrm{~nm}$ radiation for 60 seconds, using a UV lightbox. Cells were washed with PBS and then lysed in $1 \%$ Triton, $0.1 \%$ SDS, $1 \times$ protease inhibitor in $1 \times$ PBS, and protein concentrations measured using Detergent Compatible Protein Assay. 
Stock reagents of AzTB, copper (II) sulphate (CuSO4), Tris(2-carboxyethyl)phosphine hydroxide (TCEP) and Tris(benzyltriazolylmethyl)amine (TBTA) were prepared previously and frozen in aliquots as described below.

\begin{tabular}{|l|l|l|l|}
\hline Reagent & Stock concentration & Stock solvent & Concentration \\
\hline AzTB & $10 \mathrm{mM}$ & DMSO & $100 \times$ \\
\hline CuSO $_{4}$ & $50 \mathrm{mM}$ & $\mathrm{H}_{2} \mathrm{O}$ & $50 \times$ \\
\hline TCEP & $50 \mathrm{mM}$ & $\mathrm{H}_{2} \mathrm{O}$ & $50 \times$ \\
\hline TBTA & $10 \mathrm{mM}$ & $\mathrm{DMSO}$ & $100 \times$ \\
\hline
\end{tabular}

A 'click mix' was prepared with sequential addition of 1:2:2:1 ratios of AzTB:CuSO4:TCEP:TBTA and mixed. For each $100 \mu \mathrm{L}$ of protein in a CuAAC reaction, $6 \mu \mathrm{L}$ of 'click mix' was be added to give final reaction concentrations of $6 \mu \mathrm{M} \mathrm{AzTB}, 120 \mu \mathrm{M}$ copper(II) sulphate (CuSO 4$), 120 \mu \mathrm{M}$ Tris(2-carboxyethyl)phosphine hydroxide (TCEP) and $6 \mu \mathrm{M}$ Tris(benzyltriazolylmethyl)amine (TBTA). For pull-down experiments, $250 \mu \mathrm{g}$ CuAAC reactions at $2 \mathrm{mg} \mathrm{mL}^{-1}$ were agitated with click reagents at RT for 1 hour, before quenching with the addition of $5 \mathrm{mM}$ ethylenediaminetetraacetic acid (EDTA) final concentration. Proteins were precipitated with $\mathrm{MeOH}$ and $\mathrm{CHCl}_{3}$, and washed with $\mathrm{MeOH}$, as described above. Protein pellets were resuspended in $50 \mu \mathrm{L} 10 \mathrm{mM}$ DTT, 0.5\% SDS in PBS and sonicated to dissolve, before dilution with $75 \mu \mathrm{L}$ of PBS, resulting in a final concentration of $0.2 \%$ SDS. $10 \mu \mathrm{L}$ of each sample was taken for 'input' samples, and kept on ice for future comparisons. For each sample, $35 \mu \mathrm{L}$ of Neutravidin-agarose beads were washed with $0.2 \%$ SDS in PBS $(3 \times 500 \mu \mathrm{L})$. Samples were added to the prepared Neutravidin-agarose beads and agitated gently at RT for 1 hour. The supernatant was discarded, and beads washed with $0.2 \%$ SDS in PBS $(3 \times 500 \mu \mathrm{L})$, before the addition of $16 \mu \mathrm{L} 4 \times$ NuPAGE LDS sample buffer containing $5 \% \beta$-mercaptoethanol. The beads were boiled for 10 minutes at $95^{\circ} \mathrm{C}$, before collecting the supernatants as the 'pull-down' samples. Input samples were also diluted with $1 \times$ loading buffer. Labelled and enriched proteins were separated by mass by SDS-PAGE on $12 \%$ gels. The SDS-PAGE gels of fluorescently labelled proteins were imaged using a Typhoon FLA 9500 (GE Healthcare) using 532/575 nm excitation/emission wavelengths at $750 \mathrm{~V}$. Proteins were then transferred to membranes and analysed by western blotting as described above.

\section{Photoaffinity Chemical Proteomics}

THP1 cells were seeded in 6 well plates 72 hours prior to the experiment. Media was removed and replaced with fresh RPMI media containing $250 \mathrm{ng} \mathrm{mL}^{-1} \mathrm{LPS}$ and chosen concentrations of IMP2070 and MCC950 for 3 hours. Each condition was performed in triplicate, with 2 wells of cells for each replicate. Cells were UV irradiated, washed and lysed as described above. CuAAC reactions were set up at $600 \mu \mathrm{g}\left(2 \mathrm{mg} \mathrm{mL}^{-1}\right)$ with AzRB as described above and agitated at RT for one hour. Reactions were quenched with $5 \mathrm{mM}$ EDTA, and proteins precipitated as above before pellets were left to dry at RT until visibly dry. Protein pellets were resuspended in $120 \mu \mathrm{L} 10 \mathrm{mM}$ DTT, 0.5\% SDS in PBS and sonicated to dissolve. Tubes were centrifuged to check the pellet was fully dissolved, before dilution with further $180 \mu \mathrm{L}$ of PBS, resulting in a final concentration of $0.2 \%$ SDS. For each sample, $80 \mu \mathrm{L}$ of Neutravidin-agarose bead slurry was washed with of $0.2 \%$ SDS in PBS $(3 \times 1000 \mu \mathrm{L})$. Proteins were added to the equilibriated beads and agitated gently at RT for 2 hours. The supernatant was discarded, and beads washed with $1 \%$ SDS in $50 \mathrm{mM} \mathrm{HEPES} \mathrm{pH} 8.0(3 \times 1000 \mu \mathrm{L})$.

$5 \mathrm{mM}$ TCEP and $10 \mathrm{mM}$ CAA in $50 \mathrm{mM}$ HEPES pH 8.0 was added to the beads and the samples shaken at RT for 30 minutes. Supernatants were removed and the beads washed with $50 \mathrm{mM}$ HEPES $(3 \times 300 \mu \mathrm{L})$, before resuspending in $28 \mu \mathrm{L} 50 \mathrm{mM}$ HEPES. To each sample $0.2 \mu \mathrm{g}$ Trypsin was added and agitated overnight at $37^{\circ} \mathrm{C}$. 
$0.08 \mathrm{mg}$ TMT10plex ${ }^{\mathrm{TM}}$ Isobaric Mass Tag Labelling Reagent (Thermo Scientific) were dissolved in $30 \mu \mathrm{L}$ proteomics-grade MeCN. The supernatant containing the peptides were collected from the trypsinised samples, and added to the corresponding TMT reagent. TMT reactions were shaken at $\mathrm{RT}$ for two hours before quenching with $1 \mu \mathrm{L} 5 \%$ hydroxylamine ( $\mathrm{vol} / \mathrm{vol}$ ) in $\mathrm{H}_{2} \mathrm{O}$. Samples were combined within their 10-plex and evaporated to dryness using a SpeedVac concentrator (ThermoFisher).

Samples were further fractionated into 6 layers on stage-tip membranes, which were prepared by the insertion of 3 layers of sulfonic acid (SCX) membrane into $200 \mu \mathrm{L}$ pipette tips as previously reported. ${ }^{1}$ Tips were placed in $2 \mathrm{~mL}$ tubes with perforated lids, before activation of the membranes with the addition of $150 \mu \mathrm{L} \mathrm{MeCN}$ followed by centrifuging at $1,100 \times \mathrm{g}$ for two minutes, then equilibration with the addition of $150 \mu \mathrm{L} \mathrm{H}_{2} \mathrm{O}$ followed by centrifuging at $1,100 \times \mathrm{g}$ for two minutes. Buffers were prepared as described below:

\begin{tabular}{|l|l|}
\hline Buffer & Composition \\
\hline Fraction 1 & $75 \mathrm{mM}$ ammonium formate, $20 \%(\mathrm{v} / \mathrm{v}) \mathrm{MeCN}, 0.5 \%(\mathrm{v} / \mathrm{v})$ formic acid \\
\hline Fraction 2 & $125 \mathrm{mM}$ ammonium formate, $20 \%(\mathrm{v} / \mathrm{v}) \mathrm{MeCN}, 0.5 \%(\mathrm{v} / \mathrm{v})$ formic acid \\
\hline Fraction 3 & $200 \mathrm{mM}$ ammonium formate, $20 \%(\mathrm{v} / \mathrm{v}) \mathrm{MeCN}, 0.5 \%(\mathrm{v} / \mathrm{v})$ formic acid \\
\hline Fraction 4 & $300 \mathrm{mM}$ ammonium formate, $20 \%(\mathrm{v} / \mathrm{v}) \mathrm{MeCN}, 0.5 \%(\mathrm{v} / \mathrm{v})$ formic acid \\
\hline Fraction 5 & $400 \mathrm{mM}$ ammonium formate, $20 \%(\mathrm{v} / \mathrm{v}) \mathrm{MeCN}, 0.5 \%(\mathrm{v} / \mathrm{v})$ formic acid \\
\hline Fraction 6 & $5 \%$ ammonium hydroxide, $80 \%(\mathrm{v} / \mathrm{v})$ formic acid \\
\hline
\end{tabular}

The dried peptides were resuspended in $150 \mu \mathrm{L} 1 \%$ TFA in $\mathrm{H}_{2} \mathrm{O}$, and centrifuged for 5 minutes at maximum speed at RT. $135 \mu \mathrm{L}$ of the samples were added to the stage tip, before tip centrifugation at $1,100 \times \mathrm{g}$ for 2 minutes, or until all the sample had passed through the membrane. Samples were desalted with three washes of $60 \mu \mathrm{L}$ of $0.2 \%$ TFA in $\mathrm{H}_{2} \mathrm{O}$ and centrifugation at $1,100 \times \mathrm{g}$ for 2 minutes, or until all the solution had passed through the membrane. The stage tip was transferred to a new, labelled collection tube and the first fraction eluted with $60 \mu \mathrm{L}$ Fraction 1 buffer and centrifugation at 1,100 $\times \mathrm{g}$ for 2 minutes, or until all the solution had passed through the membrane. For each following fraction, the stage tip was then transferred to a new, labelled collection tube and the peptides eluted as described with $60 \mu \mathrm{L}$ of the corresponding elution buffer. Samples were evaporated to dryness before storing at $-80^{\circ} \mathrm{C}$.

Stage-tip filters were prepared by the insertion of 3 layers of PVDF Durapore Filter into $10 \mu \mathrm{L}$ pipette tips as described above. The stage tips were inserted into the caps of labelled LC-MS vials. Samples were resuspended in $10 \mu \mathrm{L}$ of $2 \% \mathrm{MeCN}, 0.5 \%$ TFA in LC-MS grade $\mathrm{H}_{2} \mathrm{O}$, and added to the stage tips before centrifugation at $4000 \times \mathrm{g}$ for 3 minutes, or until the sample had passed through the membrane. Peptides were separated on an EASY-SpraTM Acclaim PepMap C18 column (Thermo Fisher Scientific) using a 3-hour gradient of $0-100 \%$ (solvent A $2 \% \mathrm{MeCN}$ with $0.1 \%$ formic acid; solvent $\mathrm{B} 80 \% \mathrm{MeCN}$ with $0.1 \%$ formic acid) at a flow rate of $250 \mathrm{~nL} / \mathrm{min}$. This coupled to a QExactive mass spectrometer (Thermo Fisher Scientific). Survey scans were acquired from 350 to $1800 \mathrm{~m} / \mathrm{z}$, with the 10 most abundant isotope patterns with charge +2 or higher from each scan selected and fragmented further in MS/MS scans. The following settings were used:

- maximum ion injection time: survey scan 20 ms; MS/MS scans 120 ms

- ion target value: survey scan $10^{6}$; MS/MS $10^{5}$

- intensity threshold: $8.3 \times 10^{2}$

Peptide searches were performed in MaxQuant (version 1.6.0.7) using default parameters, except for the ones listed hereafter. Under group-specific parameters and type, reporter ion MS2 was selected, and the appropriate TMT10plex labels selected for lysines and N-termini, with their corresponding correction factors. Oxidation (M) and acetyl (protein N-term) were set as variable modifications and carbamidomethyl $(C)$ was set as a fixed modification. Trypsin/P 
was set as the digestion mode and re-quantify and match between runs were enabled. Searches were run in the built-in Andromeda search engine using the human Swissprot curated database with isoforms. Data analysis was performed in Perseus (version 1.6.2.3). Reporter intensity corrected values were loaded, and data was filtered against 'only identified by site', 'reverse', and 'potential contaminants'. Data was log2 transformed and filtered by valid values, retaining those that had 2 valid values in each triplicate condition. TMT data was normalized by subtracting the mean of each row within each TMT plex, before median subtraction across samples (columns). Volcano plots were generated using a pairwise Student's T-Test.

\section{Thermal Protein Profiling}

THP1 cells were seeded in 6-well plates 72 hours prior to the assay. Cells were treated with $250 \mathrm{ng} \mathrm{mL}^{-1}$ LPS and $0.1,1.0,5.0$ or $10.0 \mu \mathrm{M}$ MCC950 or DMSO for 3 hours. The media was removed and the cells washed with PBS, before the addition of non-enzymatic cell dissociation buffer. The plates were incubated on ice for ten minutes while the cells dissociated. Cells were then washed with PBS, and pelleted by centrifugation at 200 RCF for 5 minutes. The cells were resuspended in $400 \mu \mathrm{L}$ PBS containing protease inhibitor and each condition aliquoted into 4 PCR tubes of $90 \mu \mathrm{L}$. Samples were then heated for 3 minutes in a thermal cycler at $50.5,54,57$ and $60^{\circ} \mathrm{C}$ for each concentration. The cells were then held at RT for 3 minutes before lysis by repeated freeze-thaw cycles, and centrifugation at 17,000 $\times \mathrm{g}$ for 20 minutes at $4{ }^{\circ} \mathrm{C}$. Soluble proteins (supernatant) were transferred onto a new tube and $70 \mu \mathrm{L}$ of each sample was precipitated and reduced and alkylated as previously described, before addition of $0.3 \mu \mathrm{g}$ trypsin and overnight incubation at $37^{\circ} \mathrm{C}$. TMT10plex ${ }^{\mathrm{TM}}$ Isobaric Mass Tag Labelling Reagents were prepared and incubated with the trypsinised peptides as described above. 50.5 and $60^{\circ} \mathrm{C}$ samples of each concentration were in pooled into one 10-plex TMT set, and the 54 and $56^{\circ} \mathrm{C}$ into a second 10-plex TMT set. Samples were subjected to 6-layer fractionation and stage tipped as described above. Mass spectrometry analysis and peptide search using MaxQuant (version 1.6.0.1) were performed as above. ProteinGroups output file was loaded into Perseus (version 1.6.0.2) was filtered against 'only identified by site', 'reverse', and 'potential contaminants'. Data was log2 transformed and filtered by valid values, retaining only those with $100 \%$ valid values. *

For pseudo melt curves (Figure S2B), from *, a two-sample test was performed between the TMT runs, and biased proteins removed. Data was then normalised within each concentration by the subtraction of the $50.5^{\circ} \mathrm{C}$ value for that concentration. Proteins were identified as potential binders of MCC950 if there was an observable dose-dependent shift in the pseudo melt curve of the protein towards a higher temperature in at least two concentrations of MCC950 when compared to DMSO treated samples.

For analysis within temperature sets (Figure 3D), from *, TMT data was normalized by subtracting the mean of each row within each TMT plex, before median subtraction across samples (columns). Proteins were identified as potential binders of MCC950 if there was an observable dose-dependent increase in the quantity of soluble protein present at two or more temperatures.

\section{CA2 activity assay}

Recombinant CA2 (Sigma-Aldrich, C6165) was dissolved in $12.5 \mathrm{mM}$ Tris, $75 \mathrm{mM} \mathrm{NaCl}$ $\mathrm{pH}$ 7.5. Esterase activity was assessed with the following final concentrations: $5 \mu \mathrm{g} \mathrm{mL}^{-1} \mathrm{CA} 2$,

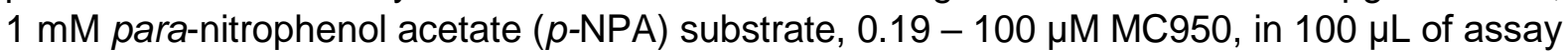
buffer (12.5 mM Tris, $75 \mathrm{mM} \mathrm{NaCl} \mathrm{pH} \mathrm{7.5).} \mathrm{The} \mathrm{reactions} \mathrm{were} \mathrm{initiated} \mathrm{with} \mathrm{the} \mathrm{addition} \mathrm{of}$ $p$-NPA and were measured by monitoring the formation of 4-nitrophenol at $405 \mathrm{~nm}$ every 90 seconds at $37^{\circ} \mathrm{C}$. Initial reaction rates were calculated by taking away background $p$-NPA hydrolysis and plotting absorbance against time. For Line-Weaver Burk analysis, the assay was performed with $2.5 \mu \mathrm{g} \mathrm{mL}^{-1} \mathrm{CA} 2,2.56-100 \mu \mathrm{M} \mathrm{MCC} 950$, and $125 \mu \mathrm{M}-1 \mathrm{mM}$-NPA, 
and reaction rates calculated as described. Each experiment was set up as technical triplicates and the means of those plotted and used for statistical analyses, and concentrations of $p$-NP product calculated using the reported extinction coefficient of $18,000 \mathrm{M}^{-1} \mathrm{~cm}^{-1}$. MCC950 purity was confirmed by LC-MS and NMR to affirm that inhibition was not due the presence of sulfonamide impurities: ${ }^{1} \mathrm{H}$ NMR $(400 \mathrm{MHz}$, DMSO-d 6 ) $\delta 7.53(\mathrm{~s}, 1 \mathrm{H}), 7.36(\mathrm{~d}, J=1.1 \mathrm{~Hz}, 1 \mathrm{H})$, $6.76(\mathrm{~s}, 1 \mathrm{H}), 6.55(\mathrm{~d}, J=1.1 \mathrm{~Hz}, 1 \mathrm{H}), 4.91(\mathrm{~s}, 1 \mathrm{H}), 2.75(\mathrm{t}, J=7.4 \mathrm{~Hz}, 4 \mathrm{H}), 2.66(\mathrm{t}, J=7.1 \mathrm{~Hz}$, $4 \mathrm{H}), 1.34(\mathrm{~s}, 6 \mathrm{H})$. LC-MS 18 minutes, $2-98 \% \mathrm{MeCN}$ in $\mathrm{H}_{2} \mathrm{O}$, retention time 12.98 minutes, ESI $\mathrm{m} / \mathrm{z}[\mathrm{M}+\mathrm{H}]^{+}=427.20$.

\section{Molecular Docking}

Molecular docking studies were conducted using MOE (purchased from the CCG) using version MOE2019.0102. Amber10:EHT forcefield was selected and docking studies were performed using the in-built 'dock' function. For placement method, the triangle matcher was set to generate 50 poses using London dG scoring. Refinement was then carried out using the rigid receptor method, based on the GBVI/WSA dG scoring functionality, to give 10 final poses.

Carbonic anhydrase co-crystal structure (PDB ID 3HS4) was imported into MOE and the inbuilt 'QuickPrep' function was used. The same was performed for PDB ID 3QYK. MCC950 was imported separately into MOE and an energy minimization was performed via the 'Minimize' function. A pharmacophore, based on the native ligand in the co-crystal structure of $3 \mathrm{HS} 4$, was created whereby the five-membered aryl ring and one oxygen atom of the sulfonamide moiety were selected as features. These two features were then constrained such that both conditions were satisfied. The MCC950 structure was then docked into the co-crystal structure of $3 Q Y K$, with the ligand site defined by the native ligand, using the previously created pharmacophore. The best pose identified by the docking was then taken forward for further molecular analysis.

(1) Rappsilber, J.; Ishihama, Y.; Mann, M. Stop And Go Extraction Tips for MatrixAssisted Laser Desorption/lonization, Nanoelectrospray, and LC/MS Sample Pretreatment in Proteomics. Anal. Chem. 2003, 75 (3), 663-670. https://doi.org/10.1021/ac026117i. 


\section{Synthesis schemes}

\section{Scheme 1}
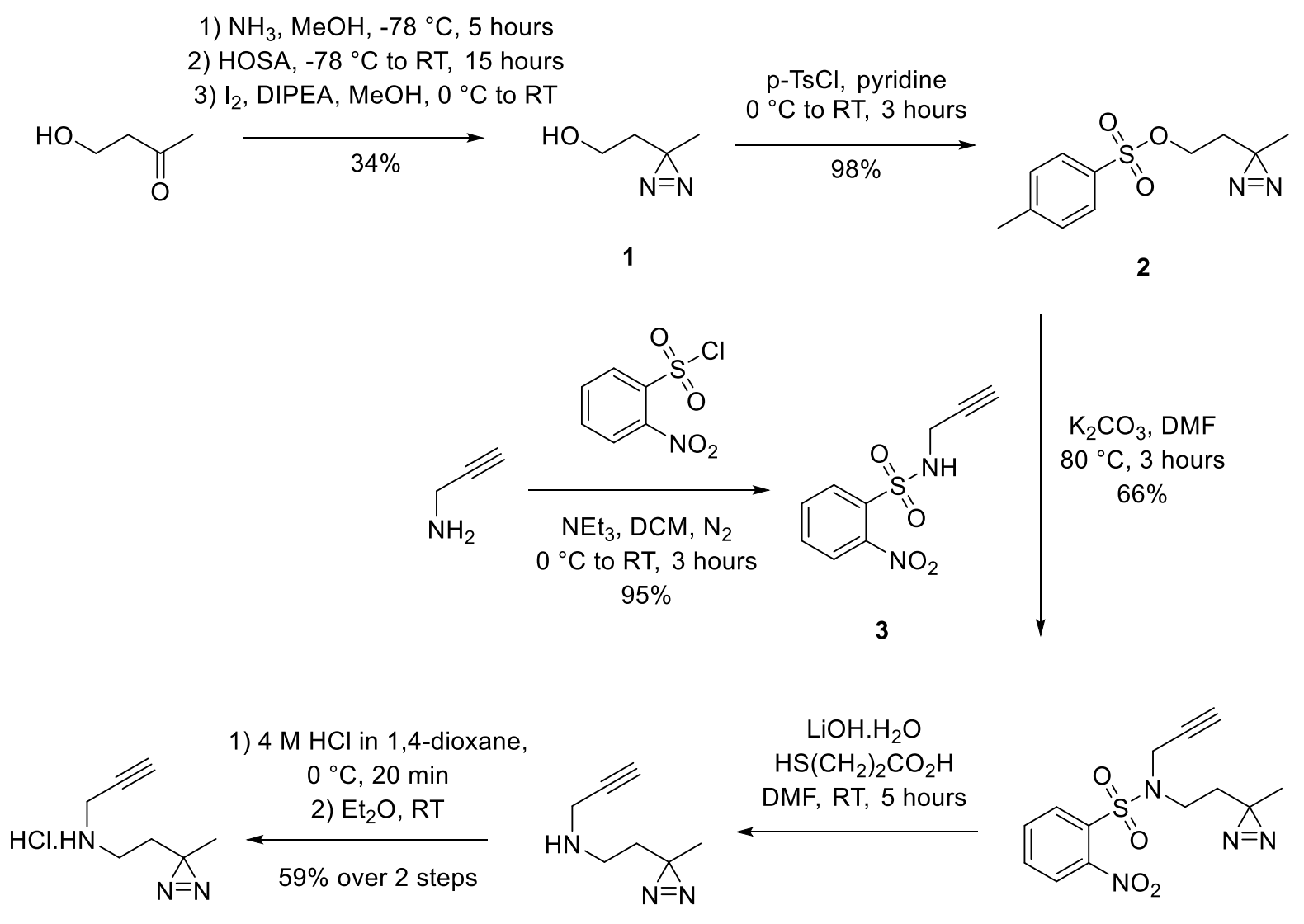

1) $4 \mathrm{M} \mathrm{HCl}$ in 1,4-dioxane,

$0{ }^{\circ} \mathrm{C}, 20 \mathrm{~min}$

2) $\mathrm{Et}_{2} \mathrm{O}, \mathrm{RT}$

5

LiOH. $\mathrm{H}_{2} \mathrm{O}$

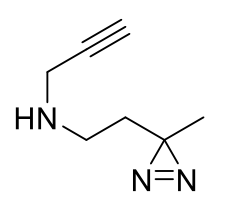

$\mathrm{HS}\left(\mathrm{CH}_{2}\right)_{2} \mathrm{CO}_{2} \mathrm{H}$

DMF, RT, 5 hours
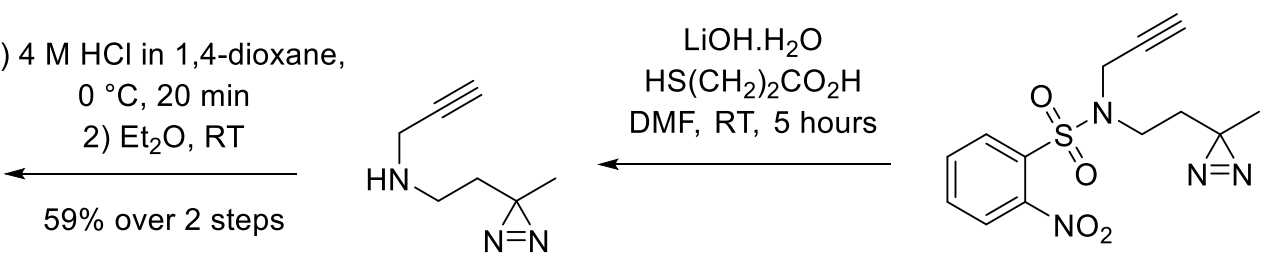

4

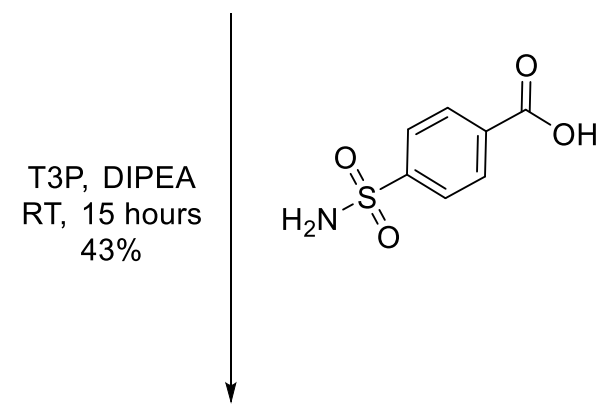<smiles>C#CCN(CCC1(C)N=N1)C(=O)c1ccc(S(N)(=O)=O)cc1</smiles> 


\section{Scheme 2}

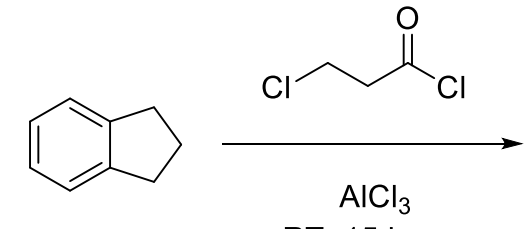

RT, 15 hours

$72 \%$<smiles>O=C(CCCl)c1ccc2c(c1)CCC2</smiles>

7<smiles>O=C=Nc1c2c(cc3c1CCC3)CCC2</smiles>

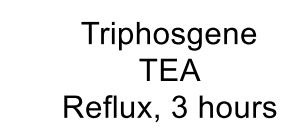

Reflux, 3 hours

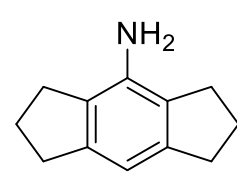

9
$\mathrm{H}_{2} \mathrm{SO}_{4}$

$55^{\circ} \mathrm{C}, 48$ hours

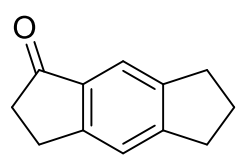

$0-5{ }^{\circ} \mathrm{C}, 1$ hour

$52 \%$ over two steps
$10 \% \mathrm{Pd}(\mathrm{OH})_{2}, \mathrm{MeSO}_{3} \mathrm{H}$

$50 \mathrm{psi}_{2}$

RT, 4 hours

$74 \%$

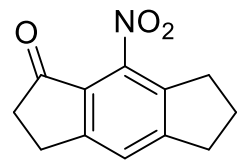

8<smiles>C#CCN(CCC1(C)N=N1)C(=O)c1ccc(S(N)(=O)=O)cc1</smiles>

$\mathrm{NaOMe}$

RT, 15 hours,

$10 \%$ over two steps<smiles>C#CCN(CCC1(C)N=N1)C(=O)c1ccc(S(=O)(=O)NC(=O)Nc2c3c(cc4c2CCC4)CCC3)cc1</smiles>

IMP2070 


\section{Supporting figures}

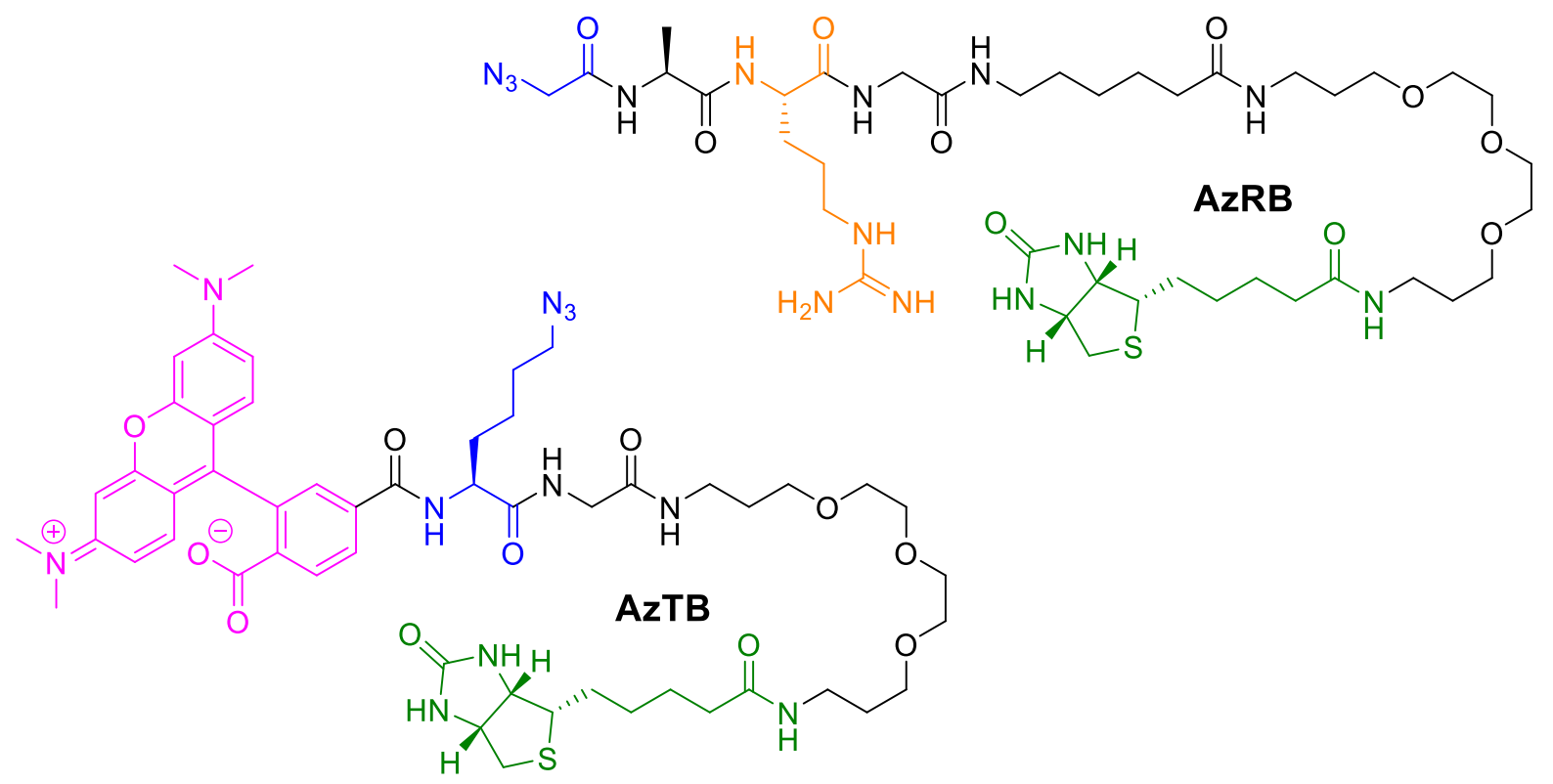

Figure S1: Capture Reagent Structures 


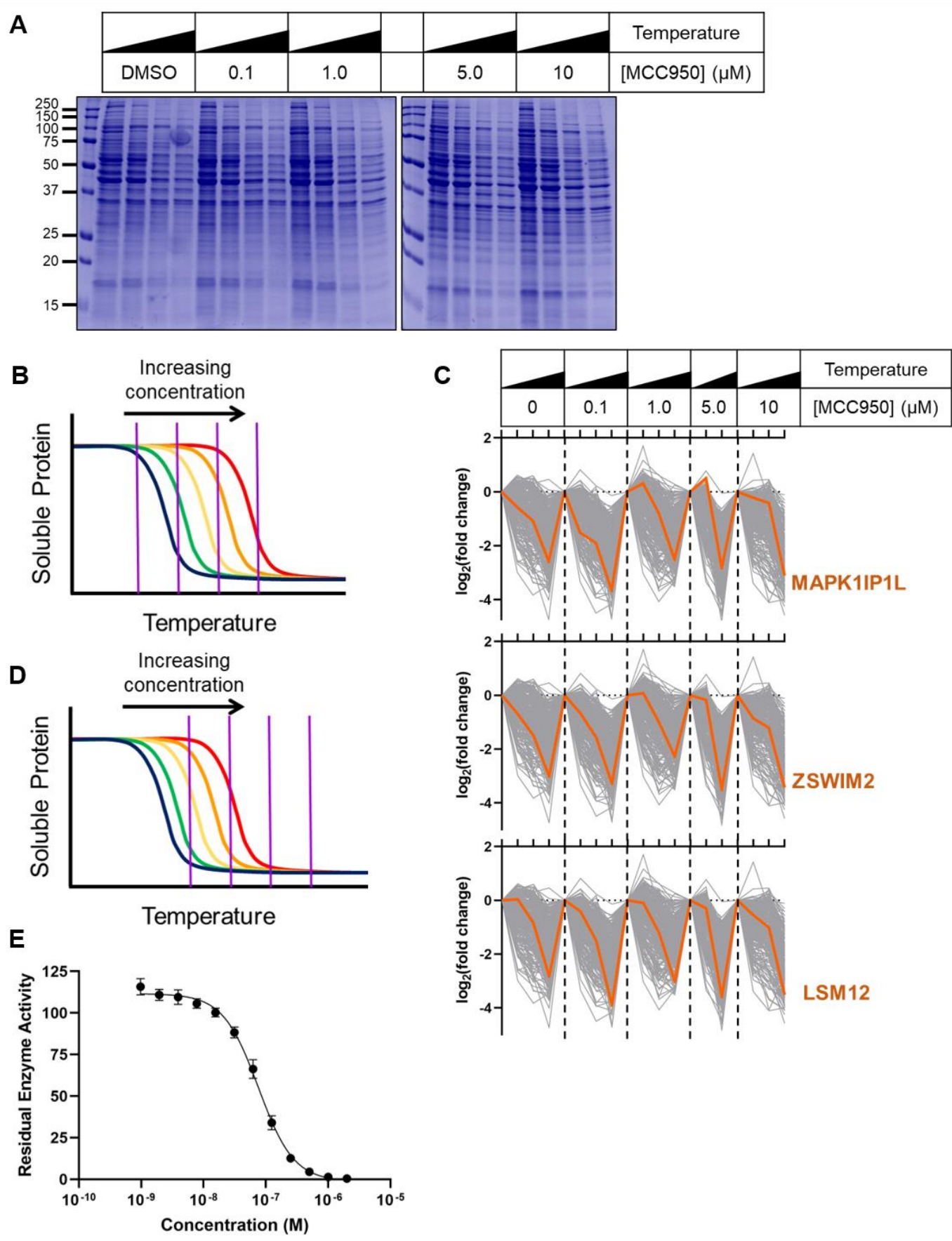

Figure S2: Proteomics Supplementary Figure

a) SDS-PAGE and coomassie analysis of soluble protein fractions used for proteomics TPP, showing uniform proteome degradation. b) Ideal coverage of $2 \mathrm{D}$ thermal protein profiling experiments, with increasing concentration of MCC950 stabilizing target proteins across the chosen temperature range. c) 'Pseudo melt curves' for TPP experiments. TMT intensities were normalized to the lowest temperature for each concentration of MCC950. The $5.0 \mu \mathrm{M}, 57^{\circ} \mathrm{C}$ data point was removed to remove anomalies. MAPK1IPL1 levels are shown as an example of a protein stabilized as the concentration of MCC950 increases; while ZSWIM2 shows weaker stabilization. LSM12 is given as a protein that is not stabilized by the presence of MCC950. d) Proteins with lower-end melt temperatures are unlikely to be sufficiently stabilized by MCC950 at higher temperatures for stabilization to be observed across the full temperature range chosen. e) Residual esterase enzyme activity of CA2 when treated with AZA. CA2 
$\left(5 \mu \mathrm{g} \mathrm{mL}^{-1}\right)$ was treated with inhibitor in the presence of $1 \mathrm{mM} p$-NPA substrate, and absorbance at $405 \mathrm{~nm}$ measured over 1 hour. Error bars represent $\mathrm{SEM}, \mathrm{N}=3 . \mathrm{IC}_{50}=0.78 \mu \mathrm{M}$; slope $=-1.53, R^{2}=0.99$.

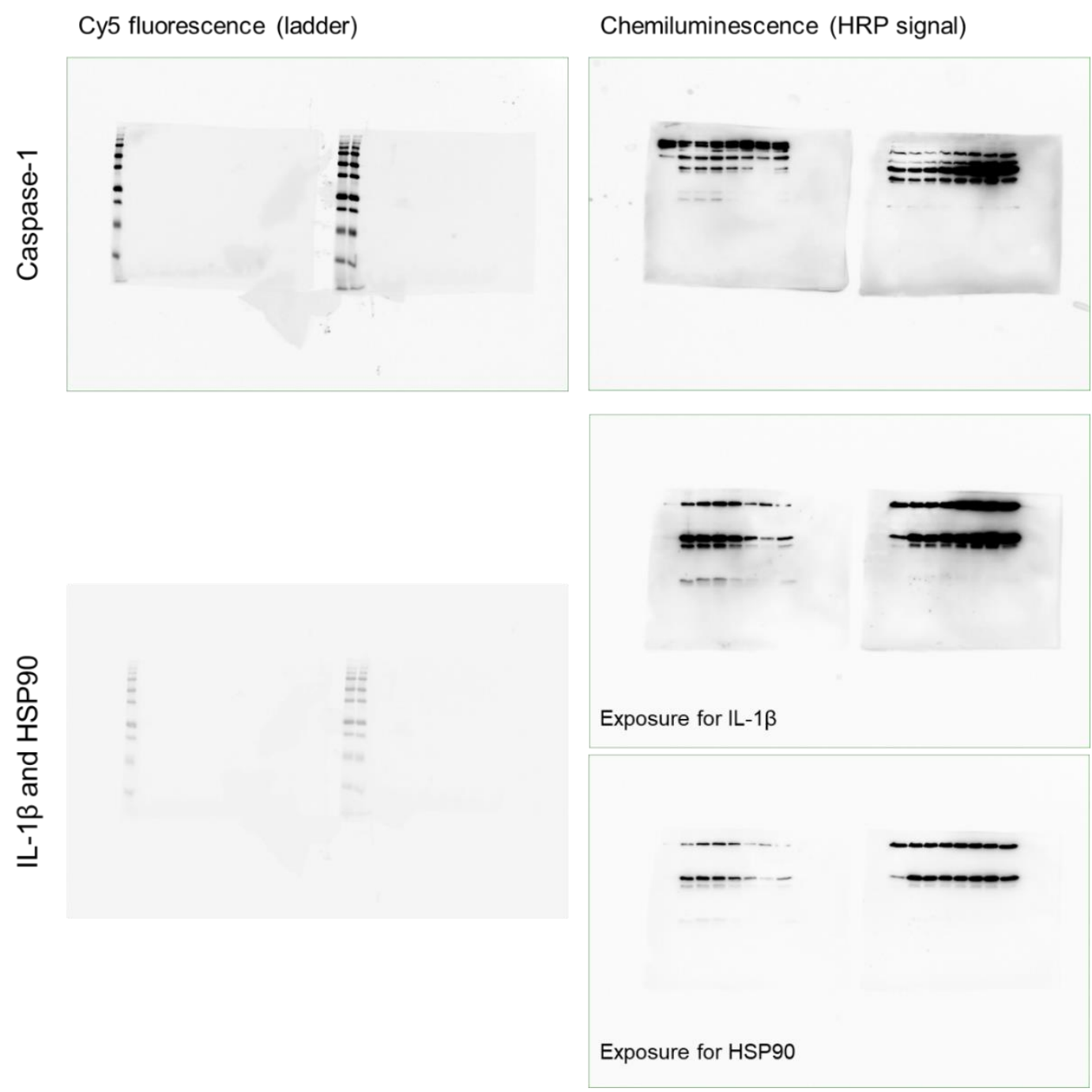

Figure S3: Uncropped blots and gels for Figure 2A 


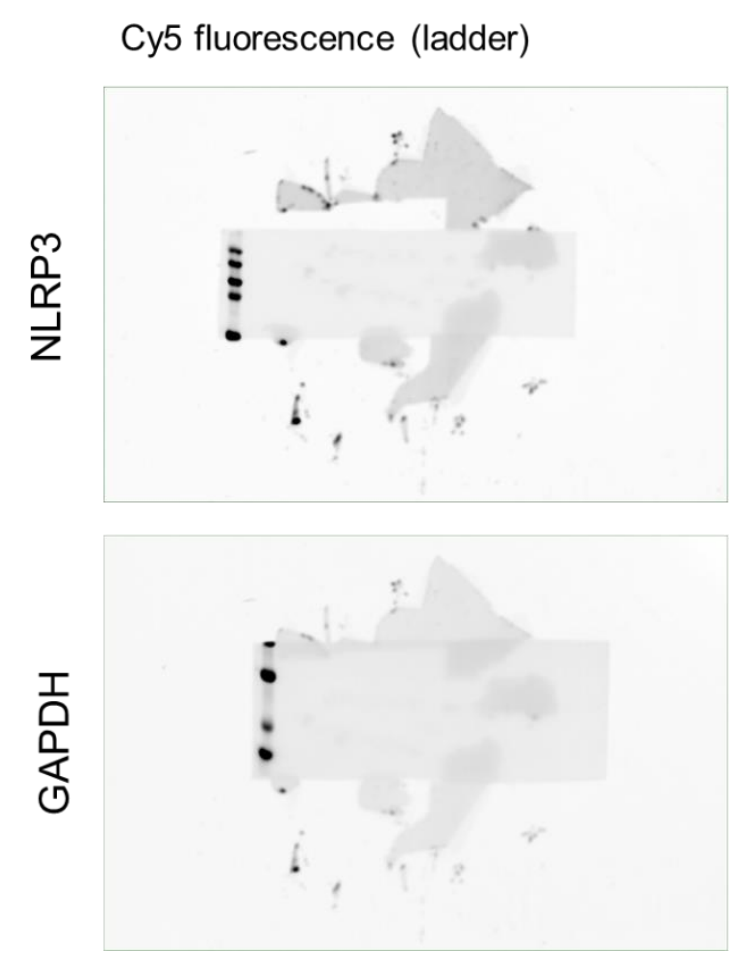

Chemiluminescence (HRP signal)

\section{TAMRA fluorescence (in gel)}

Exposure for ladder imaging

Exposure for protein labelling

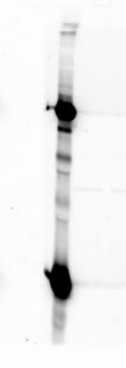

Figure S4: Uncropped blots and gels for Figure 2C 


\section{Supporting Tables}

Table S1 Proteins identified by proteomics TPP as potential MCC950 binders

\begin{tabular}{|l|l|}
\hline Gene Name & Protein \\
\hline CA2 & Carbonic anhydrase 2 \\
\hline CD99 & CD99 antigen \\
\hline CLTB & Clathrin light chain B \\
\hline DBI & Acyl-CoA-binding protein \\
\hline EEA1 & Early endosome antigen 1 \\
\hline ENO2 & Gamma-enolase \\
\hline HDDC2 & HD domain-containing protein 2 \\
\hline HIST1H1D & Histone H1.3 \\
\hline MAPK1IP1L & MAPK-interacting and spindle-stabilizing protein-like \\
\hline MRPS18C & 28S ribosomal protein S18c, mitochondrial \\
\hline MYCBP & C-Myc-binding protein \\
\hline NUP37 & Nucleoporin Nup37 \\
\hline PEA15 & Astrocytic phosphoprotein PEA-15 \\
\hline PEX19 & Peroxisomal biogenesis factor 19 \\
\hline PEX7 & Peroxisomal targeting signal 2 receptor \\
\hline PSAP & Prosaposin \\
\hline RIN2 & Ras and Rab interactor 2 \\
\hline RPL10 & 60 S ribosomal protein L10 \\
\hline RPL10A & 60 ribosomal protein L10a \\
\hline RPL15 & 60 S ribosomal protein L15;Ribosomal protein L15 \\
\hline RPL18 & 60 S ribosomal protein L18 \\
\hline RPL23 & 60 S ribosomal protein L23 \\
\hline RPL23A & 60 S ribosomal protein L23a \\
\hline RPL24 & 60 S ribosomal protein L24 \\
\hline RPL27A & 60 S ribosomal protein L27a \\
\hline ZSWIM2 & E3 ubiquitin-protein ligase ZSWIM2 \\
\hline
\end{tabular}

